\title{
DAMPAK CURRENT RATIO DAN RETURN ON EQUITY TERHADAP TRADING VOLUME ACTIVITY DENGAN PRICE TO BOOK VALUE SEBAGAI VARIABEL MODERATING PADA JAKARTA ISLAMIC INDEX PERIODE 2015 - 2019
}

\section{THE IMPACT OF CURRENT RATIO AND RETURN ON EQUITY ON TRADING VOLUME ACTIVITY WITH PRICE TO BOOK VALUE AS MODERATING VARIABLES IN THE JAKARTA ISLAMIC INDEX 2015 - 2019 PERIOD}

\author{
E. Susanti \\ Program Studi Akuntansi, Sekolah Tinggi Ilmu Ekonomi Sultan Agung, \\ Pematangsiantar \\ susantielly82@gmail.com
}

\begin{abstract}
Investors always believe that if the company performs well it can increase the volume of stock trading. Therefore, many companies are trying to increase company activity and optimize all company resources in order to increase trading volume activity. This study examines and analyzes the effect of Current Ratio, Return On Equity on Trading Volume Activity with Price To Book Value, which is a moderating variable in the Jakarta Islamic Index for the 2015 - 2019 period on the IDX. To obtain data, the website www.idx.co.id is used as secondary data. The population is 50 issuers and the sample technique uses purposive sampling, thus the sample is 10 issuers. Furthermore, the application used in analyzing quantitative data is SPSS version 21. With the results obtained, Current Ratio and Return On Equity have a significant effect on Trading Volume Activity, but Price to Book Value is not able to be a moderating variable between Current Ratio and Return On Equity to Trading. Activity Volume.
\end{abstract}

Keywords: Current Ratio, Return On Equity, Price To Book Value, Trading Volume Activity

\begin{abstract}
ABSTRAK
Investor selalu percaya bahwa jika perusahaan berkinerja baik maka dapat meningkatkan volume perdagangan saham. Oleh karena itu, banyak perusahaan yang berusaha meningkatkan aktivitas perusahaan dan mengoptimalkan seluruh sumber daya perusahaan guna meningkatkan akitivitas volume perdagangan. Penelitian ini mengkaji dan menganalisis pengaruh Current Ratio, Return On Equity terhadap Trading Volume Activity dengan Price To Book Value yang merupakan variabel moderating pada perusahaan Jakarta Islamic Index Periode 2015 - 2019 di BEI. Untuk memperoleh data digunakan situs www.idx.co.id sebagai data sekunder. Populasi sebanyak 50 emiten dan teknik sampel menggunakan purposive sampling dengan demikian sampel berjumlah 10 emiten. Selanjutnya aplikasi yang digunakan dalam melakukan analisis data kuantitaf adalah SPSS versi 21. Dengan hasil yang diperoleh Current Ratio dan Return On Equity memiliki pengaruh signifikan terhadap Trading Volume Activity namun Price to Book Value tidak mampu sebagai variabel moderating antara Current Ratio dan Return On Equity terhadap Trading Volume Activity.
\end{abstract}

Kata Kunci: Current Ratio, Return On Equity, Price To Book Value, Trading Volume Activity. 


\section{PENDAHULUAN}

Di pasar modal, terjadi transaksi perdagangan saham perusahaan dalam satu sesi perdagangan tertentu dari volume perdagangan. Volume perdagangan saham menunjukkan gambaran perdagangan atas permintaan dan penawaran para pelaku pasar saham sehingga hal ini berpengaruh terhadap volume perdagangan. Oleh sebab itu, volume perdagangan saham merupakan indikator terpenting dalam kegiatan transaksi perdagangan saham (Reny et al., 2019). Salah satu informasi yang dibutuhkan investor dalam perdagangan saham dapat dianalisis melalui laporan keuangan perusahaan. Informasi keuangan perusahaan yang disajikan pada setiap akhir periode mampu menjelaskan kinerja perusahaan kepada pihak yang memerlukan informasi tersebut. Jika perusahaan berkinerja baik artinya perusahaan mampu mengefisiensikan sumber daya yang dimiliki perusahaan dalam memperoleh laba. Hal ini terlihat dari rasio keuangan perusahaan, untuk penelitian ini peneliti hanya menggunakan $\mathrm{CR}$ dan ROE. CR mencerminkan kemampuan perusahaan dalam mengelola modal kerja perusahaan serta kemampuan dalam melunasi seluruh kewajiban jangka pendeknya. Sedangkan ROE menunjukkan keberhasilan bagi perusahaan dalam memperoleh keuntungan dengan mengoptimalkan moda perusahaan. Jadi jika CR dan ROE tinggi maka hal ini menunjukkan kinerja yang baik dengan demikian trading volume activity perusahaan akan mengalami peningkatan. Selain itu juga hal ini diperkuat oleh Nilai Price to Book Value (PBV). Jika PBV bernilai di atas satu maka hal ini menandakan bahwa perusahaan memiliki kinerja baik. Hal ini sangat baik karena semakin tinggi PBV maka diharapkan harga saham semakin tinggi dan semakin menarik bagi investor, sehingga volume perdagangan saham akan meningkat (Warizal et.al,2015).

Jakarta Islamic Index sebagai indikator Index saham di BEI dapat digunakan sebagai bahan refrensi untuk mengevaluasi kinerja perdagangan saham syariah. Indeks terdiri dari 30 perusahaan yang telah dipilih dengan beberapa kriteria penyaringan, sehingga akan terdiri dari saham saham yang sangat likuid. Gambar 1 merupakan transaksi saham perusahaan Jakarta Islamic Index periode $2015-2019$

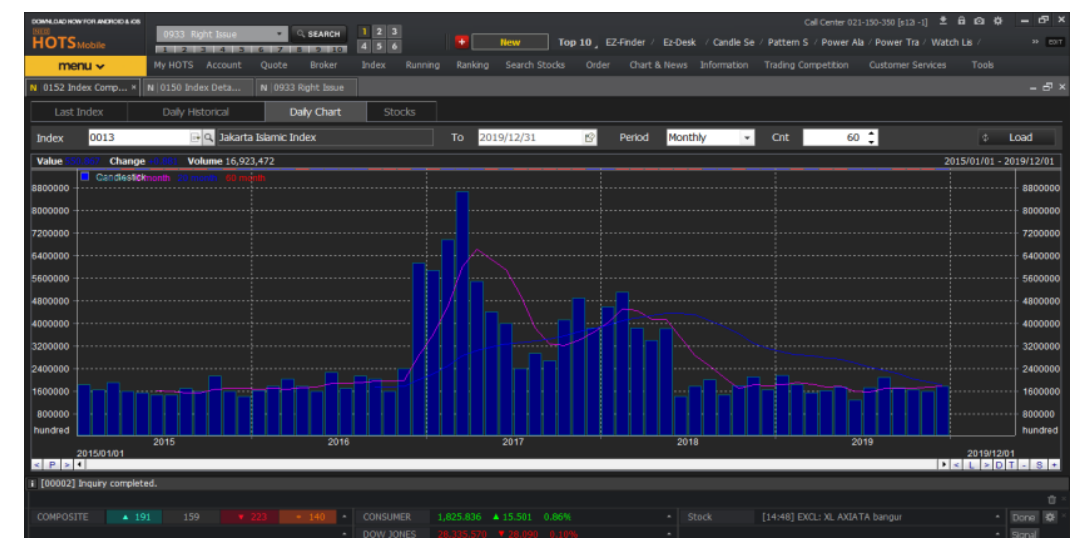

Sumber : Jakarta Islamic Index (2019)

Gambar 1 Transaksi Trading Volume Activity Periode 2015 - 2019

Dari gambar 1 tersebut dapat dilihat bahwa transaksi TVA perusahaan JII periode 2015 2016 terlihat biasa saja namun pada periode 2017 TVA mengalami peningkatkan yang cukup tajam yang terjadi pada bulan Maret
2017. Namun di bulan berikutnya TVA sudah melandai hingga pada periode 2018 hingga 2019 transaksi TVA perusahaan JII sudah kembali normal. Terdapat beberapa peneliti yang melakukan penelitian mengenai TVA 
antara lain Penelitian Chandra (2013) dengan hasil penelitian antara abnormal return sebelum dan sesudah pada saat pengumuman kenaikan harga BBM tidak memiliki perbedaan. Selanjutnya penelitian Saputra (2018) menunjukkan bahwa ROA tidak memiliki pengaruh terhadap TVA, namun Tobin's Q berpengaruh terhadap TVA. Selanjutnya penelitian Akseptori, Yunita dan Kurniasari (2018) dengan hasil penelitian baik secara parsial maupun simultan ROA, ROE, DER, TATO dan EPS tidak berpengaruh terhadap TVA. Penelitian Reny, Saleh dan Sapiri (2019) dengan hasil ROA dan Tobin'q berpengaruh positif dan signifikan terhadap Volume Perdagangan Saham. Berdasarkan ketidak konsisten tersebut maka peneliti merasa tertarik sehingga akan melakukan penelitian pengaruh $\mathrm{CR}$ dan ROE terhadap TVA dengan PBV sebagai variabel moderating pada Jakarta Islamic Index periode 2015 - 2019. Penelitian ini bertujuan untuk menganalisis serta mencari tahu pengaruh CR, ROE terhadap TVA dengan PBV sebagai variabel moderating pada perusahaan Jakarta Islamic Index periode $2015-2019$.

\section{Current Ratio (CR)}

Rasio lancar yang tinggi dapat memungkinkan perusahaan untuk melunasi hutangnya pada saat ini dan juga dapat meningkatkan nilai perusahaan (Lase et al., 2019). Rumus dari CR ini adalah

$$
\mathrm{CR}=\frac{\text { Aset Lancar }}{\text { Liabilitas Lancar }}
$$

\section{Return On Equity (ROE)}

Kemampuan perusahaan dalam memanfaatkan modal yang diinvestasikan oleh pemegang saham serta dapat mendistribusikan keuntungan tersebut kepada pemegang saham merupakan salah satu hal yang terpenting dalam pengukuran ROE. Dengan demikian ROE menguntungkan bagi investor dan pemilik perusahaan karena investor dapat memprediksi kemampuan perusahaan dalam mengambil keputusan investasi (Welly et al., 2019). Rumus ROE adalah :

$$
\text { ROE }=\frac{\text { Laba Setelah Pajak }}{\text { Total Ekuitas }}
$$

\section{Trading Volume Activity (TVA)}

Volume perdagangan adalah tinggi/rendahnya volume perdagangan di bursa efek (Rachmadani et al., 2013). TVA merupakan indikator yang bermanfaat untuk menguji respon pasar terhadap informasi. (Budiyanto et al., 2006). Rumus dari TVA ini adalah

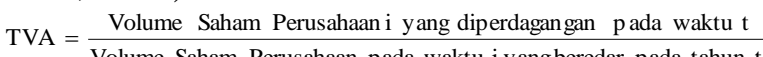

Price To Book Value (PBV)

Salah satu indikator yang digunakan untuk mengukur nilai perusahaan adalah PBV rasio ini dapat memandu investor dalam memahami persepsi investor pada risiko dan prospek perusahaan di masa depan (Welly et al., 2019). Rumus dari PBV ini adalah

$$
\mathrm{PBV}=\frac{\text { Harga Saham }}{\text { Nilai Buku }}
$$

\section{METODE PENELITIAN}

Data yang digunakan adalah data kuantitatif berupa CR, ROE, TVA dan PBV. Sumber data yang digunakan data sekunder yang diperoleh dari situs idx.co.id. Populasinya adalah Jakarta Islamic Index (JII) periode 2015 2019. Populasi terdiri dari 50 emiten, peneliti menggunakan purposive sampling sehingga sampel yang akan digunakan adalah 10 emiten. Teknik analisis data terdiri dari uji asumsi klasik, regresi linier berganda, koefisien determinasi, Uji F, Uji t dan Uji residual 
HASIL DAN PEMBAHASAN

Uji asumsi klasik

Sebelum melakukan analisis data maka data terlebih dahulu dilakukan uji asumsi klasik. Tujuannya adalah agar dapat diketahui apakah model regresi yang digunakan layak untuk diteliti. Uji normalitas

Tabel 1 Uji Normalitas

\begin{tabular}{ll|r}
\hline & & Unstandardized Residual \\
\hline N & & 50 \\
Normal Parameters & Mean &, 0000000 \\
& Std. Deviation &, 00056533 \\
Most Extreme Differences & Absolute &, 087 \\
& Positive &, 087 \\
& Negative &,- 067 \\
Kolmogorov-Smirnov Z & &, 618 \\
Asymp. Sig.(2-tailed) & &, 839 \\
\hline
\end{tabular}

Sumber : SPSS 21 data diolah 2020

Pada tabel 1 nilai Asymp Sig.(2-tailed) sebesar $0,839>$ nilai sig sebesar 0,05 maka hal ini dapat dikatakan berdistribusi normal

Tabel 2 Uji Multikolinearitas

\begin{tabular}{llll}
\hline & & \multicolumn{2}{c}{ Collinearity Statistics } \\
Model & Tolerance & VIF \\
\hline 1 & (Constant) & & \\
& CR &, 832 & 1,202 \\
& ROE &, 832 & 1,202 \\
\hline
\end{tabular}

Sumber : SPSS 21 data diolah 2020

Pada tabel 2 nilai TOL untuk variabel CR dan ROE > dari $0,10(0,832<0,10)$ dan dari $10(1,202<10)$ penelitian ini tidak nilai VIF untuk variabel $\mathrm{CR}$ dan $\mathrm{ROE}<$ menunjukkan gejala Multikolinearitas.

Tabel 3 Uji Autokorelasi

Model Summary ${ }^{\mathrm{b}}$

\begin{tabular}{llllllll}
\hline \multicolumn{7}{c}{ Change Statistics } \\
\cline { 2 - 6 } Model & $\begin{array}{c}\text { R Square } \\
\text { Change }\end{array}$ & F Change & df1 & df2 & Sig. F Change & Durbin-Watson \\
\hline 1 &, 256 & 8,101 & 2 & 47 &, 001 & 1,992
\end{tabular}

Sumber: SPSS 21 Data diolah 2020

Berdasarkan tabel 3, nilai $\mathrm{dL}=1,6283$, dU $=1,6283$ dan DW = 1,992 dapat disimpulkan bahwa dU $<\mathrm{DW}<4-\mathrm{dU}$
$(1,6283<1,992<2,3717$ maka tidak terjadi autokorelasi. 
Uji Heteroskedastisitas

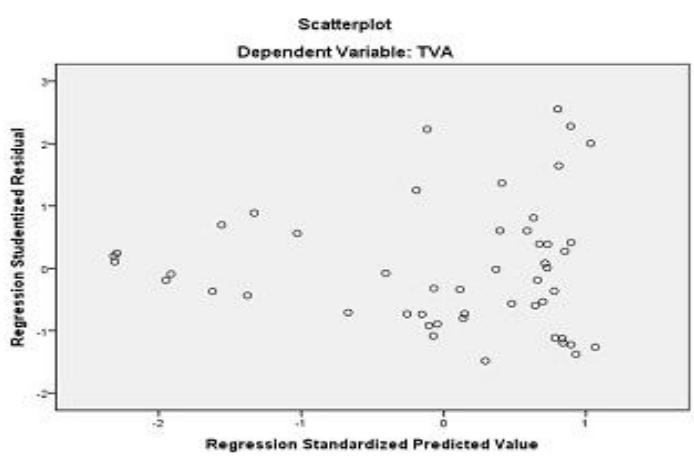

Gambar 3

Uji Heteroskedastisitas

Sumber : SPSS 21 Data di olah 2020

Berdasarkan gambar 3 sebaran data berdistribusi acak dan tidak terbentuk pola tertentu, serta angka 0 pada sumbu $Y$ berdistribusi atas dan bawah sehingga dapat disimpulkan tidak terjadi
Heteroskedastisitas. Berdasarkan hasil keseluruhan uji asumsi klasik tersebut maka penelitian ini layak untuk dilanjutkan (Zamzami dan Afif, 2015)

\section{Uji Hipotesis I}

Koefisien determinasi untuk pengujian statistik sebagai berikut :

Tabel 4

Koefisien Determinasi Hipotesis I

Model Summary ${ }^{\mathrm{b}}$

\begin{tabular}{lcccr}
\hline Model & R & R Square & Adjusted R Square & Std. Error of the Estimate \\
\hline 1 &, $506^{2}$ &, 256 &, 225 &, 00057724 \\
\hline
\end{tabular}

Sumber: SPSS 21 Data diolah 2020

Nilai Adjust $R$ square sebesar 0,225 (22,5

$\%)$ dimana pengaruh semua variabel independen (CR dan ROE) terhadap TVA sebesar 22,5\% dan untuk 72,5\% dipengaruhi oleh variabel yang tidak termasuk penelitian ini.

\section{Uji Simultan (Uji F) Hipotesis I}

Uji F pada CR dan ROE terhadap TVA seperti terlihat pada tabel 5 :

Tabel 5

Hasil Uji F Hipotesis I

\begin{tabular}{|c|c|c|c|c|c|c|}
\hline & Model & Sum of Squares & df & Mean Square & $\mathrm{F}$ & Sig. \\
\hline \multirow[t]{3}{*}{1} & Regression &, 000 & $\overline{2}$ & .000 & 8,101 &, $001^{2}$ \\
\hline & Residual &, 000 & 47 &, 000 & & \\
\hline & Total &, 000 & 49 & & & \\
\hline
\end{tabular}

Sumber: SPSS 21 Data diolah 2020

Dapat disimpulkan dari tabel 5 bahwa sig $<0,05$ adalah $0,001<0,05$ yang berarti $\mathrm{H}_{0}$ diterima dimana seluruh variabel

independen (CR dan ROE) memiliki pengaruh signifikan terhadap TVA 


\section{Uji Parsial (Uji t) Hipotesis I}

Hasil beberapa uji statistik (uji t) CR dan ROE sebagai berikut :

Tabel 6

Hasil Uji t Hipotesis I

\begin{tabular}{|c|c|c|c|c|}
\hline \multirow[b]{2}{*}{ Model } & \multicolumn{2}{|c|}{ Standardized Coefficients } & \multirow[b]{2}{*}{$\mathrm{t}$} & \multirow[b]{2}{*}{ Sig. } \\
\hline & Beta & & & \\
\hline 1 (Constant) & & & 7,715 &, 000 \\
\hline CR & &,- 369 & $-2,674$ &, 010 \\
\hline ROE & &,- 530 & $-3,840$ &, 000 \\
\hline
\end{tabular}

Sumber : SPSS 21 Data diolah 2020

Dari table 6 maka dapat dilihat secara parsial diperoleh hasil sebagai berikut :

a. Variabel CR memiliki nilai sig sebesar $0,010<0,05$ atau dengan kata lain Hipotesis diterima yakni CR berpengaruh negatif dan signifikan terhadap TVA. Dimana semakin rendah likuiditas perusahaan maka perusahaan akan dianggap mampu melunasi seluruh kewajiban lancarnya sehingga hal ini merupakan sinyal baik baik investor sehingga investor ingin melakukan pembelian akan saham perusahaan tersebut TVA mengalami peningkatan.

\section{Hasil Regresi Berganda Hipotesis I}

\section{Tabel 7}

Regresi Berganda Hipotesis I

\begin{tabular}{lcr}
\hline & \multicolumn{2}{c}{ Unstandardized Coefficients } \\
\cline { 2 - 3 } Model & B & \multicolumn{1}{c}{ Std. Error } \\
\hline 1 (Constant) &, 002 &, 000 \\
CR &, 000 &, 000 \\
ROE &,- 001 &, 000 \\
\hline
\end{tabular}

Sumber : SPSS 21 Data diolah 2020

Model Regresi untuk hipotesis pertama dapat dilihat sebagai berikut :

Uji Hipotesis II

$$
\mathrm{Y}=0,002+0,000 \mathrm{CR}-0,001 \mathrm{ROE}
$$

\section{Uji F Hipotesis II}

Tabel 8

Hasil Uji F Hipotesis II

\begin{tabular}{lrrrrr}
\hline Model & Sum of Squares & df & Mean Square & F & Sig. \\
\hline 1 Regression & 16280,639 & 2 & 8140,319 & 678,348 &, $000^{2}$ \\
Residual & 564,010 & 47 & 12,000 & & \\
Total & 16844,649 & 49 & & & \\
\hline
\end{tabular}

Sumber: SPS 21 Data diolah 2020

Berdasarkan table 8 , dapat disimpulkan $0,000<0,05$ yang berarti bahwa $\mathrm{H}_{0}$ dimana $\mathrm{CR}$ dan 
ROE berpengaruh signifikan terhadap PBV secara simultan.

\section{Uji t Hipotesis II}

Tabel 9

Hasil Uji t Hipotesis Kedua

\begin{tabular}{lrr}
\hline Model & \multicolumn{1}{c}{ t } & \multicolumn{1}{c}{ Sig. } \\
\hline CR & &, 000 \\
ROE & 33,947 &, 385 \\
\hline Sumber: SPSS & 21 Data diolah 2020
\end{tabular}

a. Variabel CR memiliki nilai sig sebesar $0,385>0,05$. Hal ini berarti Hipotesis ditolak yakni $\mathrm{CR}$ tidak memiliki pengaruh signifikan terhadap PBV. Yang artinya bahwa CR tidak memiliki kontribusi peningkatan/penurunan terhadap perusahaan.

\section{Analisis Regresi Hipotesis II}

Pengujian hipotesis II Dengan pengujian residual dengan tujuan untuk menguji variabel moderating yaitu PBV b. Variabel ROE memiliki nilai sig sebesar $0,000<0,05$. Hal ini berarti Hipotesis diterima yakni ROE memiliki pengaruh positif dan signifikan terhadap PBV. Semakin tinggi ROE maka para investor tertarik untuk melakukan investasi terhadap perusahaan sehingga hal ini dapat meningkatkan Nilai perusahaan.

dengan tujuan untuk mengetahui variabel tersebut dapat memperkuat/ memperlemah hubungan antara CR dan ROE terhadap TVA. Hasil persamaan sebagai berikut

\section{Tabel 10}

\begin{tabular}{ccr}
\multicolumn{3}{c}{$\begin{array}{c}\text { Hasil Pengujian Pengaruh CR dan ROE } \\
\text { terhadap PBV }\end{array}$} \\
\cline { 2 - 3 } Model & \multicolumn{2}{c}{ Unstandardized Coefficients } \\
\cline { 2 - 3 } & B & Std. Error \\
\hline 1 (Constant) & $-5,231$ & 1,322 \\
CR &, 454 &, 518 \\
ROE & 51,670 & 1,522 \\
\hline \multicolumn{3}{c}{ Sumber : SPSS 21 Data diolah 2020 }
\end{tabular}

Dengan hasil regresi model pertama adalah $\mathrm{M}=-5,231+0,454 \mathrm{CR}+51,670 \mathrm{ROE}$

Tujuan dari model ini agar memperoleh nilai residual dari model pertama. Sehingga hasil selanjutnya dapat disimpulkan apakah variable PBV dapat dikatakan sebagai variable moderating atau tidak. Jika variabel TVA bernilai negatif signifikan maka PBV dapat dikatakan sebagai variabel moderating. Tabel 11 menunjukkan hasil pengujian model kedua sebagai berikut :

\section{Tabel 11}

Uji residual

\begin{tabular}{|c|c|c|c|c|c|c|}
\hline \multirow{2}{*}{\multicolumn{2}{|c|}{ Model }} & \multicolumn{2}{|c|}{ Unstandardized Coefficients } & $\begin{array}{l}\text { Standardized } \\
\text { Coefficients }\end{array}$ & \multirow[t]{2}{*}{$\mathrm{t}$} & \multirow[t]{2}{*}{ Sig. } \\
\hline & & $\mathrm{B}$ & Std. Error & Beta & & \\
\hline & (Constant) & 2,858 &, 735 & & 3,888 & .000 \\
\hline & TVA & $-1085,891$ & 615,323 &,- 247 & $-1,765$ & ,084 \\
\hline
\end{tabular}

Sumber : SPSS 21 Data diolah 2020 
Model uji residual sebagai berikut :

$$
|\mathrm{e}|=2,858-1085,891 \mathrm{TVA}
$$

Dari hasil uji $\mathrm{t}$ diketahui bahwa sig $\mathrm{t}$ sebesar $0,084>0,05$ sehingga variabel

\section{KESIMPULAN}

Kesimpulan dalam penelitian ini adalah :

1. CR dan ROE secara simultan memiliki pengaruh signifikan terhadap TVA simultan pada perusahaan Jakarta Islamic Index periode 2015 - 2019

2. CR dan ROE secara parsial sama sama memiliki pengaruh negatif dan signifikan terhadap TVA periode 2015 - 2019

3. PBV tidak mampu memperkuat/memperlemah hubungan antara CR, ROE terhadap TVA pada Jakarta Islamic Index periode 2015 2019.

DAFTAR PUSTAKA

Akseptori, R., Yuniati, N., \& Kurniasari, P. I. (2018). Fundamental Terhadap Trading Volume Activity Pada Perusahaan Industri Transportasi Laut Dan Perikanan Di Bursa Efek Indonesia. Jurnal Teknologi Dan Terapan Bisnis, 1(2), 90-97. https://doi.org/https://doi.org/10.0301/ jttb.v1i2.41

Lasmana, A., \& Ashariah, L. (2019). Prediksi Return Saham Pada Perusahaan Sektor Pertambangan Yang Terdaftar Di Bursa Efek Indonesia. JURNAL AKUNIDA, 5(1), 24-37.

Budiyanto, A., Ismani, \& Ngadirin. (2006). Analisis Trading Volume Activity (TVA) dan Abnormal Return Pada Saham Perusahaan Yang Tercatat dalam Jakarta Islamic Index (JII) Sebelum dan Setelah Bergabung Dengan JII. Jurnal Pendidikan Akuntansi Indonesia, 5(1). https://doi.org/https://doi.org/10.2183 1/jpai.v5i1.863

Chandra, T. (2013). The Impact Of Fuel Price Increase On Stock Price In Indonesia Stock Exchange. Journal of Economics, Business \& Accountancy VENTURA, 16(3), 385-
PBV bukan merupakan variabel moderating yang dapat memperkuat/memperlemah hubungan antara CR dan ROE terhadap TVA.

398.https://doi.org/http://dx.doi.org/1 0.14414/jebav.v16i3.219

Lase, A. Z., Jubi, Susanti, E., \& Putri, D. E. (2019). Pengaruh Likuiditas, Aktivitas Dan Profitabilitas Terhadap Nilai Perusahaan Pada Perusahaan Sub Sektor Kabel Yang Terdaftar Di Bursa Efek Indonesia. Sultanist Jurnal Manajemen Dan Keuangan, 7(1), 56-63. https://doi.org/https://doi.org/10.3740 3/sultanist.v7i1.137

Rachmadani, S., Kertahadi, \& Yaningwati, F. (2013). Analisis Perbedaan Trading Volume Activity Sebelum dan Sesudah Stock Split. Jurnal Administrasi Bisnis (JAB), 1(2), 3844.http://administrasibisnis.studentjou rnal.ub.ac.id/index.php/jab/article/vie $\mathrm{w} / 38$

Reny, A. R., Saleh, M. Y., \& Sapiri, M. (2019). Pengaruh Return On Asset Dan Tobin's Q Terhadap Volume Perdagangan Saham Pada Perusahaan Perbankan Yang Listing Di Bursa Efek Indonesia Periode Tahun 2013-2017. Indonesian Journal of Business and Management, 1(2), 9-16. https://doi.org/https://doi.org/10.3596 5/jbm.v1i2.294

Saputra, I. (2018). Pengaruh Roa Dan Tobin's Q Terhadap Volume Perdagangan Saham Pada Perusahaan Pertambangan Yang Terdaftar Di Bursa Efek Indonesia Tahun 2011-2014. Dinamika Ekonomi, Jurnal Ekonomi Dan Bisnis, 11(1), 66-75. https://stienasypb.ac.id/jurnal/index.php/jdeb/article /view/98

Warizal, W., Nirwanti, N., \& Setiawan, A. B. (2019). Return On Invesment (Roi), Economic Value Added (Eva), Dan Return Saham: Studi Empiris Pada Perusahaan Lq45. JURNAL 
AKUNIDA, 5(2), 47-58.

Welly, Y., Susanti, E., Azwar, K., \& Grace,

E. (2019). Leverage Dan

Profitabilitas Terhadap Nilai

Perusahaan Serta Ukuran

Perusahaan Sebagai Variabel

Zamzami, K. K., \& Afif, M. N. (2015).

Pengaruh Return On Asset (Roa),

Debt To Equity Ratio (Der),

Current Ratio (Cr), Dan Total

Assets Turnover (Tat) Terhadap

Return Saham Pada Perusahaan

Yang Masuk Dalam Kategori

Indeks Lq-45 Di Bursa Efek

Indonesia. Jurnal Akunida, 1(1), 27-

34.
Moderat Pada Perusahaan

Makanan Dan Minuman. Financial Jurnal Akuntansi, 5(2), 1-10. https://doi.org/https://doi.org/10.3740 3/financial.v5i2.115 